\title{
Editorial: Sedimentology and Society
}

\author{
Amanda Owen ${ }^{1 *}$, Michael Clare ${ }^{2}$ and Barbara Mauz ${ }^{3}$ \\ ${ }^{1}$ School of Geographical and Earth Sciences, University of Glasgow, Glasgow, United Kingdom, ${ }^{2}$ National Oceanography \\ Centre, University of Southampton Waterfront Campus, European Way, Southampton, United Kingdom, ${ }^{3}$ Department of \\ Geography and Geology, University of Salzburg, Salzburg, Austria
}

Keywords: sedimentology, society, natural hazards, pollutant dispersal, carbon transfer and storage, coastal change

\section{Editorial on the Research Topic}

\section{Sedimentology and Society}

Earth surface processes are increasingly affected by human activities, often resulting in complex, or unexpected consequences for society. The on-going effects of land-use changes and release of pollutants to the natural environment are of growing concern. Societal awareness of these environmental changes has grown rapidly over the past decade, prompting a need to better understand and predict the implications of future changes, and to inform adaptation and mitigation policies and strategies. Sedimentology is critical in understanding complex interplays between human activities and earth-surface processes by characterizing and quantifying the response of nature to human impact and vice versa, the impact of natural processes on society. Thus, while key challenges exist, there are many opportunities for sedimentologists to advance the understanding of the human-nature relationship (Hodgson et al., 2018) and thereby contribute to achieving the UN sustainability goals (United Nations Sustainable Development Goals, 2015). Research Topics of this contribution include natural hazards, pollutant dispersal, carbon transfer and storage, and Earth's surface response to changing climate and sea level. This Frontiers in Earth Science special issue brings together a collection of papers that bridge key knowledge gaps in these critical areas, and document the challenges and opportunities within the theme "Sedimentology and Society."

\section{OPEN ACCESS}

Edited and reviewed by:

David Mark Hodgson,

University of Leeds, United Kingdom

*Correspondence:

Amanda Owen

amanda.owen@glasgow.ac.uk

Specialty section:

This article was submitted to Sedimentology, Stratigraphy and

Diagenesis,

a section of the journal

Frontiers in Earth Science

Received: 07 January 2020

Accepted: 22 January 2020

Published: 11 February 2020

Citation:

Owen A, Clare M and Mauz B (2020)

Editorial: Sedimentology and Society.

Front. Earth Sci. 8:19.

doi: 10.3389/feart.2020.00019

\section{NATURAL HAZARDS}

Sedimentology plays a key role in improving our understanding of the frequency and impact of a wide range of geohazards that directly and indirectly impact communities. Five earthquakes with a magnitude $>9$ occurred in the last century, causing major economic damage and loss of life. The AD 2011 Tohoku-oki earthquake occurred along the hadal Japan Trench, generating the largest-ever recorded co-seismic slip and a tsunami with coastal run-up heights of up to $40 \mathrm{~m}$, with more than 15,000 recorded fatalities (Bassett et al., 2016). Instrumental records of such events only extend c.100 years, while historical records lack detail on location, magnitude and mechanics. Subaqueous landslide deposits potentially provide a valuable archive of ancient earthquakes to extend such catalogs. Kioka et al. document $>2000$ years of earthquake activity along the hadal Japan Trench through detailed analysis of deposits across the trench, providing new insights into the behavior of earthquakes along the subduction zone, and how large volumes ( $>7$ trillion grams) of organic carbon are mobilized during earthquakes. Besides earthquakes, natural hazards are created through other events such as volcanic or tropical cyclone activity (Pelling and Uitto, 2001). Small Island Developing States are particularly vulnerable to such natural hazards, partly owing to their remote location. Vanuatu has been described as the most disaster-prone nation in the South Pacific (Meheux and Parker, 2006); a location where Clare et al. document the complex and cascading interactions that can arise from volcanic activity, tropical cyclones, dam bursts and river floods. They discuss how 
climatic and land-use changes may play a more important role than volcanic or tectonic events in preconditioning and triggering natural hazards on many small volcanic islands.

\section{POLLUTANT DISPERSAL}

As natural systems become modified and polluted by human activities, it is essential that we understand the complexities from source to sink in sedimentary routing systems; in particular how pollutants and particulates are liberated, transported and deposited within these systems. Fine-grained sediment can impact aquatic ecosystems, water quality, and increase flood risk. The implications of future climate change may also affect the rate and nature of such transport. Richardson et al. use a numerical model to simulate the effect of projected global warming and precipitation on the dispersal of fine-grained particles throughout the River Derwent (UK) catchment. They demonstrate how seasonal land-use can dramatically disrupt sediment transport, and alter the potential for erosion. The effect of plastic pollution in the natural environment is another growing concern (Eriksen et al., 2014). While many studies have focused on terrestrial aquatic systems (e.g., Lebreton et al., 2017), the deep sea is thought to be the ultimate sink for plastics (Woodall et al., 2014); much of which occurs in the form of tiny fragments and fibers (microplastics). Less than 1\% of the plastic in the ocean floats on the surface (Jambeck et al., 2015; Van Sebille et al., 2015). Kane and Clare discuss where that missing plastic may accumulate, through a summary of the deep-sea processes that may transport this human-made particle, and lay out a number of future research directions to fill key but outstanding knowledge gaps in this field.

\section{CARBON TRANSFER AND STORAGE}

There has undoubtably been an increase in atmospheric $\mathrm{CO}_{2}$ over the last century (Intergovernmental Panel on Climate Change, 2014; Abram et al., 2019). Understanding natural stores of $\mathrm{CO}_{2}$ is critical as we try to reduce, and mitigate against, the release of natural carbon; however existing estimates of natural carbon sequestration still remain poorly constrained, which limits our understanding of the carbon cycle as a whole. Spatial heterogeneity of sedimentary deposits appears to be the dominant control on where organic carbon hotspots occur, as also suggested by Kioka et al.; hence future studies should aim to characterize such variability. Smeaton and Austin perform a detailed study in mid-latitude fjords, to better constrain the spatial and depth-related variability in natural organic carbon sequestration. Carbon Capture and Storage can offer a promising

\section{REFERENCES}

Abram, N., Gattuso, J. P., Prakash, A., Cheng, L., Chidichimo, M. P., Crate, S., et al. (2019). "Framing and context of the report," in IPCC Special Report on the Ocean and Cryosphere in a Changing Climate, eds H. O. Pörtner, D. C. Roberts, V. Masson-Delmotte, P. Zhai, M. Tignor, E. Poloczanska, K. Mintenbeck, A. Alegría, M. Nicolai, A. Okem, J. Petzold, B. Rama, and N. M. Weyer. Available anthropogenic solution to mitigating against the release of $\mathrm{CO}_{2}$, particularly as it can utilize existing petroleum fields. Olivarius et al. explore how sedimentological variations can influence the reactivity and storage potential of $\mathrm{CO}_{2}$ within sandstone reservoirs using the Gassum Formation in Skagerrak as a case study example.

\section{MANAGING THE COAST AND SHALLOW MARINE ENVIRONMENTS}

Coastlines are often population density hotspots. With sea level rise being a real threat to many coastlines, understanding how systems migrate and adapt is key. Mulhern et al. analyse a dataset of modern and ancient barrier islands, to understand the linkages between processes and deposit architecture. The authors present a comprehensive and novel dataset of barrier island morphologies that allows conclusions on barrier island morphodynamics to be drawn upon. The authors show where linkages between modern and ancient deposits can, and importantly, cannot be drawn upon. Coastal and shallow marine environments are also key environments for the growth in renewable energy. Wind turbines are being installed in progressively deeper water, in larger arrays, to maximize energy yield and efficiency. Greater water depths and larger sites bring challenges for foundation design, particularly where the subsurface geology is complex. Emery et al. investigate one of the largest proposed offshore wind farm sites, at the Dogger Bank in the UK North Sea. The glacially generated highly variable stratigraphy of the Dogger Bank results from past phases of glaciation and ice-retreat. The paper improves our knowledge on ground conditions for designing wind turbines. Studies that link modern and ancient deposits can provide critical insights into how systems react to external forcing as well as gain insights into the three-dimensional form in the subsurface.

This collection of papers is designed to be a starting point of bringing together a variety of disciplines with the overarching aim of addressing how sedimentology can help better understand and mitigate against societal issues.

\section{AUTHOR CONTRIBUTIONS}

All authors listed have made a substantial, direct and intellectual contribution to the work, and approved it for publication.

\section{FUNDING}

MC acknowledges support from NERC National Capability project Climate Linked Atlantic Sector Science (NE/R015953/1). 
plastic pieces weighing over 250,000 tons afloat at sea. PLoS ONE 9:e111913. doi: 10.1371/journal.pone.0111913

Hodgson, D. M., Bernhardt, A., Clare, M. A., Da Silva, A. C., Fosdick, J., Mauz, B., et al. (2018). Grand challenges (and great opportunities) in sedimentology, stratigraphy, and diagenesis research. Front. Earth Sci. 6:173. doi: 10.3389/feart.2018.00173

Intergovernmental Panel on Climate Change (2014) Climate Change 2014: Synthesis Report. Contribution of Working Groups, I., II and III to the Fifth Assessment Report of the Intergovernmental Panel on Climate Change, eds Core Writing Team, R. K. Pachauri and L. A. Meyer (Geneva: IPCC), 151. doi: $10.1017 /$ CBO 9781107415416

Jambeck, J. R., Geyer, R., Wilcox, C., Siegler, T. R., Perryman, M., Andrady, A., et al. (2015). Plastic waste inputs from land into the ocean. Science 347, 768-771. doi: $10.1126 /$ science. 1260352

Lebreton, L. C., Van der Zwet, J., Damsteeg, J. W., Slat, B., Andrady, A., and Reisser, J. (2017). River plastic emissions to the world's oceans. Nat. Commun. 8:15611. doi: 10.1038/ncomms15611

Meheux, K., and Parker, E. (2006). Tourist sector perceptions of natural hazards in Vanuatu and the implications for a small island developing state. Tourism Manag. 27, 69-85. doi: 10.1016/j.tourman.2004.07.009

Pelling, M., and Uitto, J. I. (2001). Small island developing states: natural disaster vulnerability and global change. Global Environ. Change Part B 3, 49-62. doi: $10.1016 / S 1464-2867(01) 00018-3$
United Nations Sustainable Development Goals (2015). United Nations Sustainable Development Goals. Available online at: http://www.un.org/ sustainabledevelopment/sustainable-development-goals/ (accessed January 30, 2020).

Van Sebille, E., Wilcox, C., Lebreton, L., Maximenko, N., Hardesty, B. D., Van Franeker, J. A., et al. (2015). A global inventory of small floating plastic debris. Environ. Res. Lett. 10:124006. doi: 10.1088/1748-9326/10/12/ 124006

Woodall, L. C., Sanchez-Vidal, A., Canals, M., Paterson, G. L., Coppock, R., Sleight, V., et al. (2014). The deep sea is a major sink for microplastic debris. R. Soc. Open Sci. 1:140317. doi: 10.1098/rsos. 140317

Conflict of Interest: The authors declare that the research was conducted in the absence of any commercial or financial relationships that could be construed as a potential conflict of interest.

Copyright (๑) 2020 Owen, Clare and Mauz. This is an open-access article distributed under the terms of the Creative Commons Attribution License (CC BY). The use, distribution or reproduction in other forums is permitted, provided the original author(s) and the copyright owner(s) are credited and that the original publication in this journal is cited, in accordance with accepted academic practice. No use, distribution or reproduction is permitted which does not comply with these terms. 